\title{
'Not Black Enough': Changing Expressions of Coloured Identity in Post-Apartheid South Africa
}

\author{
MOHAMED ADHIKARI \\ University of Cape Town
}

I have argued elsewhere at great length that Coloured identity was remarkably stable and experienced relatively little fundamental change in the way it functioned as a social identity throughout that period of white supremacist rule from the formation of the South African state through to the ending of apartheid. ${ }^{1}$ Expressions of Coloured identity have, in contrast, undergone rapid transformation in the post-apartheid environment. The past decade has been a time of flux and unprecedented change in the way Colouredness has operated, and indeed, has needed to operate as a social identity. Not only has the new democratic dispensation brought with it a degree of freedom of association and possibilities for ethnic mobilisation inconceivable under white domination, but it has also undermined, even invalidated, some of the most basic assumptions and practices that had underpinned Coloured identity from the time it had crystallised in the late nineteenth century. And with the racial hierarchy that had regulated social relations in white-ruled South Africa having broken down in important respects, intergroup relations have become more complex and expressions of social identity more fluid. While this has, on the one hand, compounded the confusion and controversy that have dogged the identity in recent decades, it has also opened up opportunities for new ways of conceptualising Colouredness and brought forth more varied and creative responses to questions about the nature of Coloured identity and its role in South African society. It is thus not surprising that the new

1. M. Adhikari, 'Hope, Fear, Shame, Frustration: Continuity and Change in the Expression of Coloured Identity in White Supremacist South Africa, 1910-1994' (PhD thesis, University of Cape Town, 2002). The central argument of the dissertation is that Coloured identity is better understood not as having evolved through a series of transformations during this period, as conventional historical thinking would have it, but to have remained surprisingbly stable throughout the era of white rule. This is not to contend that Coloured identity was static or that it lacked fluidity, but that the continuities during this period were more fundamental to the way in which it operated as a social identity than the changes it experienced. It is argued at some length that this stability was derived from a central core of enduring characteristics that regulated the way in which Colouredness functioned as an identity during this period. For the core of the argument, see especially pp. 7-8 and 24-43. 
political paradigm and ongoing swift social transformation have stimulated innovative attempts at marshalling Coloured ethnic resources. This article seeks to explain why Coloured identity, given its prior history of relative stability, has experienced rapid and, in some respects, thorough-going change in the past decade and to explore new social and political dynamics informing these shifts.

Despite the emergence of a vocal, Coloured rejectionist voice within the nonracial democratic movement of the 1980s, the past decade and a half has witnessed a resurgence of Colouredism with many people who had rejected the identity reembracing it. Fear of African majority rule, perceptions that Coloureds were being marginalised, a desire to counter pervasive negative stereotyping of Coloured people, and attempts at capitalising on the newly democratic environment in pursuit of political agendas have all played a role in fuelling Coloured assertiveness in the new South Africa. ${ }^{2}$ It has become commonplace for Coloured people disaffected with the new South Africa to express their disgruntlement by lamenting that 'first we were not white enough and now we are not black enough'. This claim has very rapidly become clichèd, because it reflects popular sentiment within the greater part of the Coloured community and highlights key dilemmas Coloured people face in coming to grips with the post-apartheid environment. Besides accentuating their interstitial position within a transforming South African racial hierarchy, it very neatly captures their perennial predicament of marginality. Though for many Coloured people the adage 'the more things change, the more they stay the same' rings true regarding their position in the new South Africa, few will deny that their lives have been profoundly affected by the changes of the last decade. While the responses of the majority are still informed by apartheid-style thinking, elements within the Coloured community have nevertheless been creative about the manner in which they express their social identity.

The most obvious reason expressions of Coloured identity have experienced swift innovation in post-apartheid South Africa is that change was forced upon it because the political environment altered suddenly and drastically after F.W. de Klerk's landmark speech of 2 February 1990. A radical re-ordering of the political landscape during the transition to democracy compelled re-assessment of allegiances and re-alignment of priorities throughout South African society. Continued rapid social and economic transformation has ensured a fluid milieu conducive to the remoulding of all social identities, not least Coloured identity.

Importantly in the case of Coloured identity, political reform brought with it a significant increase in the political influence of the Coloured community which heightened the salience of the identity. Democratic government, for the first time, gave the Coloured community voting power commensurate with its demographic

2. Some aspects of Coloured identity in the new South Africa are dealt with in W. James et al, Now That We Are Free Coloured Communities in a Democratic South Africa (Cape Town, 1996) and Z. Erasmus, ed., Coloured by History, Shaped by Place New Perspectives on Coloured Identities in Cape Town (Cape Town, 2001). 
profile. This influence came into play well before 1994 in that, soon after the unbanning of the African National Congress (ANC), leaders and organisations across the political spectrum began lobbying with increasing urgency for support within the Coloured community, in anticipation of the need to strengthen their hands in negotiations and in expectation of having to mobilise for forthcoming elections. Because of their concentration in the western third of the country where they formed a majority of the population, it was clear to all from the start of negotiations for a new dispensation that Coloured support was essential to political success in those areas that were later to become the provinces of the Western and Northern Cape. ${ }^{3}$ Nelson Mandela's urging of the ANC in 1992 to recognise 'Coloured ethnicity' as a political reality was an important step in the public acknowledgement of the existence of Coloured identity by the radical left. ${ }^{4}$ These appeals to Coloured group consciousness had the effect of reinforcing Coloured exclusivity because they contributed to the reification of Coloured identity, undermined the non-racial stance of the rejectionist movement that had developed during the 1970s and 1980s, and promoted the expression of political interests along racial lines. Strenuous attempts to win the Coloured vote and hand-wringing responses to Coloured voting patterns have subsequently served only to accentuate Coloured exceptionalism and reify the identity further.

Although the use of overtly racialised political tactics have tended to ameliorate during the last decade and most political parties in the new South Africa claim to be non-racial, they are more accurately described as being multiracial in that they work with essentialist concepts of race and often openly try to exploit racial identifications. The black-peril tactics of the National Party during the 1990s, particularly in the run-up to the 1994 elections, were undoubtedly instrumental in heightening race consciousness within the Coloured community. More recently, Democratic Alliance strategies for winning Coloured support have openly played upon their fears of African domination. The ANC clearly also contributed to this process by side-lining the United Democratic Front (UDF)affiliated anti-racist lobby of the western Cape soon after its unbanning and directly soliciting Coloured support. Given the continued prevalence of racial thinking in post-apartheid South Africa, no political party aspiring to mass support could afford to ignore the popular mindset in this regard.

A concomitant influence promoting innovation in the expression of Coloured identity is that the abolition of apartheid and the advent of the democratic order have provided Coloured people with a degree of personal liberty and freedom of association never before enjoyed. One aspect of this new-found freedom is that people now have the option of expressing their social identities and ethnic

3. According to the 1996 census report, Coloureds formed a majority of 54,2 per cent in the Western Cape and 51,8 per cent in the Northern Cape.

4. M. Adhikari, 'Coloureds', in C. Saunders, advisory ed., Illustrated Dictionary of South African History (Sandton, 1994), 79. 
preferences in whichever way they please. A few organic intellectuals within the community have, for example, sought to mobilise Coloured opinion primarily through an identification with a slave past, others are trying to re-invent a Khoisan ethnic identity and yet others retreat into a laager of Coloured exclusivism. Some Coloured people have sought to promote an identification with Africa, others with various forms of rainbow nationalism, while a few adhere to an anti-racist universalism. Since 1994 there has developed a motley market-place for ideas and movements around Coloured identity with a distinctly idiosyncratic element that includes the eccentric claims of Chief Joseph Little to the chieftainship of the Hamcumqua Khoi tribe, the suggestion that a 'gangster party' ${ }^{5}$ be formed, the provocatively named Kleurling Weerstandbeweging (Coloured Resistance Movement $)^{6}$ that drew most of its support in the Coloured townships of Gauteng and the solitary effort of maverick, Peter Abrahams, who styles himself as 'Instigator' of the Movement for the Expulsion of Non-Blacks. The majority, however, particularly within the working classes, has continued to adhere to a racialised conception of Colouredness with strong affinities to whiteness and a defensive racism toward Africans which draws heavily on apartheid values. This new creativity in manifestations of Coloured identity is part of a wider flowering of cultural expression encouraged by the tolerant atmosphere of post-apartheid South Africa that self-consciously celebrates racial and cultural diversity.

It is ironic that with the abolition of legally binding race classification as enshrined in the Population Registration Act and other apartheid legislation, ${ }^{7}$ Coloured identity has gained even greater salience in South African public life than it had in the latter phases of the apartheid era. Now that those who had forcibly been classified 'Coloured' were at liberty to identify socially and politically in whichever way they desired, the majority have chosen to emphasise their Colouredness and many have done so in ways that are hostile to Africans and at times flagrantly racist. Such anti-African sentiment has surfaced most strongly at election time, fanned by opposition-party rhetoric and a voyeuristic press. The oft-heard dismissal of Mandela as 'just another kaffir' during the first years of democratic rule captures the racially motivated contempt and alienation felt within large swathes of the Coloured working classes towards the new order. The subsequent emergence of the colloquial acronym 'JACK', an abbreviation for 'just another confused Kaffir', reserved usually for the scornful dismissal of prominent

5. This led to a short-lived movement to form a party of reformed gangsters by Pastor Albern Martins, himself a reformed gangster. It would appear that Martins has in the meantime relapsed as he has been arrested and charged with illegal possession of R7 million worth of abalone and trading in cocaine: Cape Times, 14 Jan. 2005.

6. This name is provocative because it mimics the name of the Afrikaner Weerstandbeweging, the most notorious of the white, ultra-right wing parties.

7. Apartheid legislation was not completely consistent in its specification of racial categories. Compare, for example, the three broad racial categories of the Population Registration Act with the four of the Group Areas Act. 
Africans, particularly politicians or government spokesmen, is an indication that these sentiments are still common.

A principal contributor to Coloured dissatisfaction with the new order and thus an important determinant of the way the identity has found expression is that the Coloured community, especially the working classes, see themselves as having gained little, if any, tangible benefit from the new dispensation. While the skilled and well-educated Coloured middle classes have profited from the extension of civil liberties, and many have been able to take advantage of opportunities that have become available to formerly disadvantaged people through affirmative action and black economic empowerment initiatives, the Coloured working classes have been victims of jobless economic growth and an increasing desire among employers in the formal sector to hire Africans in order to have a more racially representative work force. In the Western Cape the unwinding of distortions caused by the Coloured Labour Preference Policy is not only affecting the Coloured community adversely, but is also perceived to be the result of government policy unfairly advantaging Africans. Civil rights such as the franchise and freedoms of expression and association which have clearly enhanced the lives of the Coloured middle classes have meant little to their working-class counterparts who remain mired in poverty and feel marginalised. Having the right to live where you choose, marry whom you wish and send your children to the school of your choice is of little consequence to the labouring poor of the Coloured townships.

It also needs to be taken into account that while large sections of the African poor have benefited from the provision of basic services, such as electricity, sanitation and running water, a relatively small section of the Coloured proletariat has experienced this sort of improvement in living standards. Coloured peoples' status of relative privilege under white domination ensured that the apartheid regime had, by and large, provided these services to Coloured communities and in dormitory suburbs erected to house the hundreds of thousands of people relocated under the Group Areas Act. Very importantly, the extension of social services and welfare payments to the African masses neglected under apartheid have in most cases meant a dilution in benefits from the relatively privileged levels to which Coloured recipients had become accustomed. This has caused real hardship within the Coloured proletariat and is generally seen to be the result of inequitable government policies favouring Africans. Some have even chosen to interpret government policy in this regard to be punishment of Coloured people for not supporting the ANC. Though such claims are clearly unfounded, they nevertheless feed Coloured suspicion of the ANC government as well as resentment toward Africans in general.

Indeed, a very common perception within the Coloured working classes as well as elements within the lower middle-income group is that they are worse off under the new dispensation than they were under apartheid. They cite shrinking employment opportunities, especially as a result of affirmative action, escalating crime, deteriorating social services and the rapaciousness of corrupt government 
officials, among other reasons, to support the view that 'we were better off under the white man'. There is a strong feeling that the Coloured people have traded one set of oppressors under apartheid for a larger, even more unscrupulous set of oppressors after 1994. Relying on apartheid-style reasoning, disaffected Coloured people often present themselves as victims of inherent racial traits of Africans, be it their propensity for violence, their innate corruptness or an in-born tendency to favour their own kind. Award-winning Coloured actor, Anthony Wilson, recently captured popular sentiment within the Coloured community when he claimed:

The Boers stole, but at least they budgeted and did not steal everything. They stole the cream, but the darkies are stealing the cream, the milk and the bucket. ... We [coloureds] are being victimised. We are being turned into the new slaves of our country. ... We swapped five million farmers for 34 million blacks [as our oppressors]. ${ }^{8}$

While it is all too easy to dismiss such negativity toward the new South Africa as a product of irrational racism, there is a growing body of evidence that the living standards of the Coloured proletariat have suffered significantly since the early 1990s. A study by Stellenbosch University economists, Servaas van der Berg and Megan Louw, have found that while the poverty headcount ratios of all race groups have declined between 1990 and 2000, only among Coloureds has it increased during this period. ${ }^{9}$ Their growing impoverishment has manifested itself in various ways within the Coloured working class. Not surprisingly, more and more people within this social category have found it increasingly difficult to keep up with escalations in the cost of municipal services as apartheid-era subsidies were phased out and the ANC government implemented a policy of full-cost recovery for such services. On the basis of a national survey conducted in collaboration with the Human Sciences Research Council, David McDonald, Director of the Development Studies Programme at Queens University, Canada, found that twenty per cent of Coloured respondents were regularly unable to pay for basic services such as water and electricity, and that many had suffered service cut-offs or even eviction as a result. Even people in lower middle-income groups were not immune to service delivery cut-offs. Having committed a large portion of their income to mortgage or rent payments, they were unable to afford all the services they needed..$^{10}$ Another important indicator of social stress is that crime statistics show a hugely disproportionate rise in the homicide rate among Coloured

8. Argus, 2 Apr. 2003.

9. Business Report, 26 Feb. 2004; S. van der Berg and M. Louw, 'Changing Patterns of South African Income Distribution: Toward Time Series Estimates of Distribution and Poverty' (Working paper, Department of Economics and Bureau for Economic Research, Stellenbosch University, 2003).

10. D. McDonald, 'The Bell Tolls for Thee: Cost Recovery, Cut-offs, and the Affordability of Municipal Services in South Africa', in D. McDonald and J. Pape, eds, Cost Recovery and the Crisis of Service Delivery in South Africa (Cape Town, 2002), 167, 171. 
people from the early 1990s onwards, and that Coloured people are more than twice as likely to be murdered as people of other races. While partly a legacy of the breakdown of communal and family bonds as a result of forced removals, this violence has in recent years been exacerbated by rising unemployment, increasing drug and alcohol abuse, and a growing prevalence of gangsterism and criminal activity in working-class Coloured areas. ${ }^{11}$ Whatever else one may read into these studies and statistics, what is clear is that there is some material basis to Coloured disenchantment with the new order and thus to racial antagonism towards Africans.

In the wake of the 1994 elections, a stereotype of Coloured people as particularly prone to racist behaviour has emerged. Given the continued prevalence of racial thinking and stereotyping and of inter-racial hostility between various groups in South African society, there is no justification for singling out Coloured people in this regard, and any suggestion that their attitude is somehow inherent is indefensible. What can, however, be said is that the Coloured community is highly sensitive to issues of race. This sensitivity emanates, firstly, from their marginality which has made them vulnerable in a society in which race remains the primary form of social identification and therefore of social and political solidarity. Secondly, their intermediate position in the racial hierarchy has helped sharpen Coloured peoples' awareness of racial issues which affect them both personally and as a group. It needs to be stressed, though, that Coloured racial hostility towards Africans is essentially defensive in nature and arises from their position of weakness and feelings of vulnerability. This is a key reason why these antagonisms have not yet spilt over into a single instance of serious inter-racial violence. Such racial animosity has hitherto been restricted to the trading of verbal insults and at worst has resulted in tense stand-offs over African squatter invasions of land or houses which a particular Coloured community regarded as theirs.

Coloured feelings of marginality - and of betrayal amongst some disillusioned former supporters of the anti-apartheid movement - have been deepened by a perceived loss of status by Coloured people in the new South Africa. Having all along enjoyed a position of relative privilege, many now regard Coloureds to be the lowest in the pecking order of the new South Africa, because the Africandominated government advantages its own racial constituency, while whites who continue to dominate the economy increasingly favour Africans to ingratiate themselves with the political elite. This highly selective view, which ignores the impoverished mass of Africans, tends to dwell on high-profiled African individuals and a rapidly growing and conspicuous African middle class for justification. There can be little doubt that Coloured anxieties have been

11. J. Thomson, 'A Murderous Legacy: Coloured Homicide Trends in South Africa', and T. Leggett, 'Still Marginal: Crime in the Coloured Community', both in S. A. Crime Quarterly, 7 Mar. 2004. See also Cape Times, 27 May 2004. 
exacerbated by ongoing African racial chauvism toward Coloured people and an African triumphalism that on occasion emanates from within the ranks of the ANC itself. Coloured unease has also not been calmed by the shift in emphasis from reconciliation under the Mandela presidency to the more Africanist tone of Thabo Mbeki's tenure.

Perhaps the most fundamental reason behind the need for Coloured identity to find new forms of expression is that the discrediting of racist ideologies and the abolition of apartheid have undermined the racial basis upon which the identity has operated from the time of its late nineteenth century genesis. Colouredness has always been constructed as a racial identity in the popular mind - and in much of academic writing, one might add - and was sustained by racist ideology. There can be little doubt that the driving force behind Coloured exclusivism under white rule was the promotion and protection of the relative privilege enjoyed by Coloured people in the South African racial hierarchy. The assertion of a separate Coloured identity was originally founded on a claim to higher social status and better treatment than Africans on the basis of their being assimilated into Western culture and being partly descended from European colonists. Unable to achieve the first prize of assimilating into the dominant society because of white racism, the second prize of laying claim to an intermediate status in the racial system became the mainstay of the espousal of a separate Coloured identity. The white supremacist state and the ruling establishment by and large sanctioned this claim to relative privilege because it resonated strongly with the dominant society's perception of what the social order should be, whether viewed as God-given or natural. Privileging Coloureds above Africans was also useful as part of a broader divideand-rule strategy.

The precipitate change in the political and moral climate in which Colouredness has to operate in the new South Africa has been deeply disconcerting to a large part of its political, communal and intellectual leadership which has been wrestling with the unenviable problem of re-orientating and re-articulating a profoundly racialised identity which, in addition, is compromised by a widely perceived complicity in maintaining white supremacy. The new order, with its emphasis on multi-culturalism, nation-building and the egalitarian values enshrined in its proudly progressive constitution, has invalidated what had all along been the principal strategy behind the espousal of a separate Coloured identity in white supremacist South Africa. With its racially based claim to relative privilege no longer acceptable, there has been an urgent need by politicians, community leaders and organic intellectuals to find a new basis for the espousal of the identity and new strategies for fostering Coloured group interests.

One possible response to the post-apartheid situation has been the assertion of non-racism. This option in its purist, anti-racist form has declined markedly in popularity from its apogee in the heady days of the late 1980s when the antiapartheid movement, most notably the UDF, had considerable success in promoting it to counter apartheid ideology. In the polarised world of apartheid 
South Africa, it was relatively easy to promote non-racism as an ideal. This has become much more difficult in the post-apartheid environment, where racial and ethnic identities have greater legitimacy. Despite the political correctness and rainbow rhetoric that veneers much of South African public life, the reality of racial politics in day-to-day living and the pervasiveness of racial forms of thinking have made non-racism an impractical option for those seeking to mobilise popular support. In the new South Africa the terrain of anti-racism appears largely to have been abandoned to intellectuals and some former anti-apartheid activists who continue to reject Colouredness as a form of false consciousness or whiteimposed identification. ${ }^{12}$

Since the reality of Coloured identity cannot be wished away or ignored in the political arena or other areas of public life, a more practical alternative to the strictly non-racial position has therefore become necessary for those wishing to steer expressions of Coloured identity in a more progressive direction. The most common response in this regard has been for organic intellectuals, community leaders and activists within the Coloured community to espouse a rainbowist position that accepts the reality of racial and ethnic distinctions and their identity as Coloured but that embraces the multi-culturalist precepts that all communities be accorded respect and receive equal treatment. Support of the ANC, generally viewed as the most representative and progressive party, appears to be the most popular political option among those who have adopted this stance.

An early example of an attempt to affirm Coloured identity and re-align it within a progressive, multi-culturalist framework is provided by the December $1 \mathrm{st}$ Movement which came into being in Cape Town in the latter months of 1996. The Movement, which drew its name from the freeing of slaves on this day in 1834, sought to invigorate a despondent and disunited Coloured community by kindling within it an identification with a common slave past. Finding little resonance among the mass of Coloured people and widely criticised for fostering Coloured separatism, the Movement was allowed to lapse after its first commemorative gathering on 1 December 1996. This initiative foundered on the contradiction of its desire to maintain a politically progressive approach while mobilising under the aegis of a discredited racial identity. ${ }^{13}$ A personal and more subtle attempt to come to terms with the racial baggage of Coloured identity is furnished by Zimitri Erasmus's introduction to the edited collection of essays Coloured by History, Shaped by Place, published in 2001. Erasmus argues that the only way to rupture the racialised modes of thought in which the identity is mired is to confront the reality of Coloured racism and its complicity with white supremacism head-on.

12. See, for example, Cape Times, 25 Aug. 1995; Cape Times, 28 Mar. 1996; Cape Times, 4 Dec. 1996; Mail and Guardian, 1 Dec. 2000.

13. Anonymous, 'Retracing the Path of Memory' (unpublished manuscript, African Studies Library, University of Cape Town, 1996); Cape Times, 9 Oct. 1996; Cape Times, 16 Oct. 1996; Cape Times, 17 Oct. 1996; Cape Times, 21 Oct. 1996; Cape Times, 2 Dec. 1996. 
Any form of denial or resort to essentialist notions of identity, as has been the case since the advent of democracy, will only perpetuate Coloured marginality and discomfort with the new dispensation. Most importantly, it is not only the Coloured community, but the whole of South African society that will need to develop a new mindset and a new kind of 'reflexive political practice' to relieve itself of the burden of the apartheid past. All South Africans need to recognise 'racist sentiments and practices as part of our everyday reality and the shaping of all our selves' and Coloured identity as part of a 'shifting texture of broader black experience'. ${ }^{14}$

For the greater majority of Coloured people, however, there are serious drawbacks to broadly South Africanist approaches of the sort proposed by Erasmus or the December 1st Movement. For many, racial thinking is so deeply entrenched that racially unifying approaches to politics or inter-group relations are automatically discounted as unrealistic, even delusional. Because of continued and deep-seated antipathy towards Africans within the Coloured community and perceptions of their being victimised by an African-dominated government, South African political and economic life is seen as necessarily adversarial, with cleavages drawn along racial lines. Even among those who profess to subscribe to multi-cultural values, there is fear that Coloured interests and needs will be lost sight of within any broadly South Africanist or non-racial outlook. Indeed, for many, the marginalisation of Coloured people in the new South Africa is already a reality. Rainbow nationalism has proven to be an arid ideology that is long on rhetoric but short on practical solutions to racially defined problems of South African political life. It has already become something of a clichè among Coloured people to dismiss rainbowism with the protestation that 'there is no brown in the rainbow'.

Under these circumstances one might have expected Coloured separatism to have had strong appeal, and for some organisation or movement professing Coloured exclusivist ideals to have gained widespread popularity. The reality is that initiatives such as the Kleurling Weerstandbeweging, the Brown Nationalist Front, the Brown Democratic Party and the Coloured Forum have remained completely marginal or have existed in name only. The only separatist movement to have struck a chord within the Coloured community, and a relatively feeble one at that, is Khoisan revivalism, the first high-profiled example being the Pan Africanist Congress's former secretary general, Benny Alexander's, renunciation in 1994 of his conventional name in favour of 'Khoisan X'. The revivalist movement reached its apogee when over 440 delegates representing 36 Khoisan communities and organisations came together at the National Khoisan Consulta-

14. Erasmus, Coloured by History, 13-28. For a detailed evaluation of Erasmus's book, see M. Adhikari, 'Coloured Identity and Creolization in Cape Town', Social Dynamics, 29, 1 (2003), $158-70$. 
tive Conference in Oudtshoorn between 29 March and 1 April 2001. The movement has found scant support among the mass of Coloured people and there has been little evidence of formal organisation between various Khoisan groupings since then. Outside of the small number of people, largely in the Northern Cape, that have all along regarded themselves as being of Khoisan descent, manifestations of Khoisan identity have been episodic and mainly in evidence on festive and symbolic occasions such as Heritage Day celebrations and the return of the remains of Sarah Baartman.

Khoisan revivalism is a movement only in the broadest sense of the term, as there has over the past decade been a profusion of groups and individuals with a variety of agendas who have claimed Khoisan identity. There also appears to be a good deal of mutual antagonism between various revivalist groups and selfproclaimed leaders or 'chiefs' who vie with each other for recognition and ascendancy. Khoisan revivalism is in essence both exclusionist and Coloured rejectionist. It is rejectionist in that Khoisan identity is proudly affirmed as an authentic culture of ancient pedigree in place of Colouredness which is repudiated as the coloniser's perverted caricature of the colonised. It is exclusionist in that the claim to being the true indigenes of South Africa, even when not articulated as a demand for first-nation status, nevertheless represents a new argument for a position of relative privilege. It is exclusionist in another sense as well, in that at the Khoisan Consultative Conference there was general agreement that Muslims and Malays did not qualify as being Khoisan. ${ }^{15}$

The overall sense one has regarding Coloured identity in the new South Africa is one of fragmentation, uncertainty and confusion. Whereas for the greater part of its existence Coloured identity was accepted as given by its bearers, and while in the latter phases of the apartheid era the emergence of a rejectionist movement created a schism between those who accepted and those who eschewed it, the new South Africa has witnessed the emergence of a wide spectrum of positions on the nature of Colouredness and a plethora of initiatives to change or influence the ways in which it is expressed. Such attempts have thus far failed to have much of a popular impact because they lack resonance with the Coloured masses and are driven by small groups of intellectuals and community activists with limited influence.

The evidence indicates that many people who have gone beyond simply accepting racial categories as given are wrestling with questions of to what extent they should express their identity as black, as African, as South African, as Coloured, as Khoisan, as descendants of slaves, or to make a stand on the principle of non-racism. There is often confusion about whether Colouredness is inherent or imposed from outside, whether it is something negative and to be discarded or

15. Personal communication by Nigel Penn, Department of Historical Studies, University of Cape Town, who attended the conference as an observer, 16 July 2004. 
something positive and to be embraced and affirmed. The identity is in flux and is undergoing a degree of change last experienced with its emergence in the late nineteenth century. 